\title{
Eunomius and Gregory of Nyssa on the Principle of 'the More and the Less' and Its Application to the Category of Substance
}

\author{
Dmitry Biriukov \\ National Research University Higher School of Economics (HSE) \\ dbirjuk@gmail.com
}

\begin{abstract}
Gregory of Nyssa at the outset of his 'Against Eunomius' cites Eunomius, where the latter speaks about "greater and lesser" activities. However, discussing this quotation later in the treatise, Gregory misinterprets the words of Eunomius. He reads Eunomius as if he applied the principle of 'the more and the less' not to activities but to substances. Such interpretation cannot be proved on the basis of what Eunomius actually wrote. Actually, the two opponents (Gregory of Nyssa and Eunomius) used the same Aristotelian position, which prohibits the application of the principle of 'the more and the less' to the category of substance. This position was used by the two polemists in order to argue against each other. At the same time, Gregory developed his own philosophical system founded on the principle of 'the more and the less' in the course of this polemics with Eunomius.
\end{abstract}

\section{Keywords}

substance - activity - categories - Arian controversy - the principle of 'the more and the less' - Aristotelianism - Trinity

* The article was prepared within the framework of the Basic Research Program at the National Research University Higher School of Economics (HSE) and supported within the framework of a subsidy by the Russian Academic Excellence Project '5-100'. 
In the first book of Against Eunomius, Gregory of Nyssa cites Eunomius's Second Apology. It is worth noting that the Second Apology is available to us only through these very citations. Gregory cites the following part of the text:

The whole statement of our doctrines consists of the highest and most authentic substance; of the one which exists because of that substance and after that substance has supremacy over all the rest, and of a third which is in no way aligned with them, but subject to the one because of causation and to the other because of the activity by which it exists; the activities which accompany the substances and the names belonging to them being of course treated together for the comprehensive statement of the whole doctrine. But again, since each of these substances both is and is perceived to be absolutely simple and altogether one in its own rank, and since the activities are defined at the same time as their works, and the works match the activities of those who effected them, there is surely every necessity both that the activities accompanying each of the substances are lesser and greater, and that some occupy the first and others the second rank, and in sum that they reach the same degree of difference as their works reach. For it would not be right to speak of the same activity by which he made the angels, or the stars and heaven, or man; but just as works may be senior to and more honorable than other works, so also one of a truly religious mind would say that they produce identical works, and varied works reveal varied activities. Since these are such and in their relation to each other preserve the bond invariable, those who conduct their investigation in accordance with the inherent order of things and do not insist on mixing and confusing everything together, will surely be right, should any dispute arise about the substances, to base their belief about what is being demonstrated and the resolution of disputed points on the primary activities peculiar to the substances, and to resolve any doubt about the activities with reference to the substances, and to reckon it surely more fitting and generally more accomplished to descend from primary to secondary things. ${ }^{1}$

1 Gregory of Nyssa, Contra Eunomium I.1.151.1-154.13 (Gregorii Nysseni opera. Contra Eunomium Libri I et II, pars prior, ed. W. Jaeger, Leiden, 196o, pp. 71-73); El 'Contra Eunomium I' en la produccion literaria de Gregorio de Nisa. vi Coloquio Internacional sobre Gregorio de Nisa, Ed. F. Mateo Seco, J. Bastero, Pamplona, 1988, pp. 57-58, slightly revised: Пâऽ $\delta \tau \hat{\omega} \nu x \alpha \theta^{\prime} \dot{\eta} \mu \hat{\alpha} \varsigma$

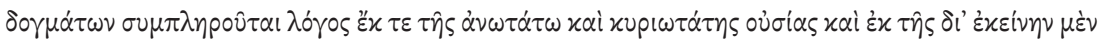

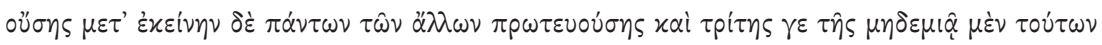

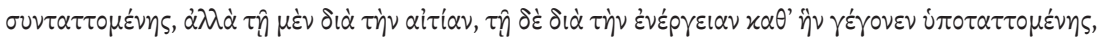

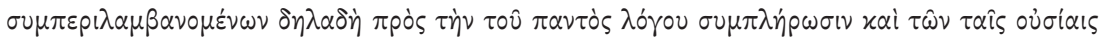

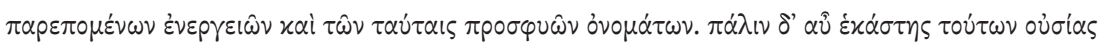


Gregory cites this text in order to scrutinize it in meticulous detail within his own treatise (cf. I.1.150.1-5) ${ }^{2}$. Gregory takes issue with Eunomius's claim that the works of the Son and the Holy Spirit are inferior to those of the Father, while the works of the Holy Spirit are inferior to those of the Son. As a response to this claim, Gregory of Nyssa develops his doctrine of God's limitlessness and applies this characteristic to the hypostases of the Son and the Holy Spirit. Thereupon Gregory argues that we cannot apply the principle of 'the more and the less' to the Father, the Son, and the Holy Spirit. Next, Gregory proves the fundamental unfitness of the principle of 'the more and the less' for an individual per se. In his analysis of Eunomius's statement that the Son and the Holy Spirit came into existence by being generated from the Father (a statement with which Gregory is at odds), Gregory suggests considering this topic with regard to the human species, specifically the descendants of Abraham. By doing this, he shows the absurdity of the principle of 'more and the less' when applied to human individuals. Gregory affirms that some people come into being before, some after. One person generates another, and that one in due time generates other people. However, what is important is that each of these human individuals has the same human substance. Therefore, David, for example, is no less a human individual than say Abraham, and each of them

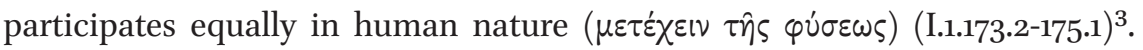

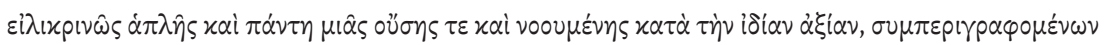

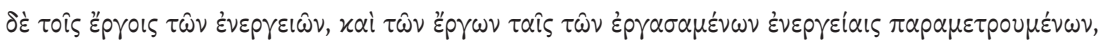

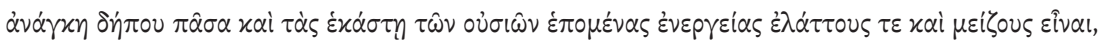

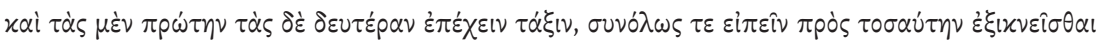

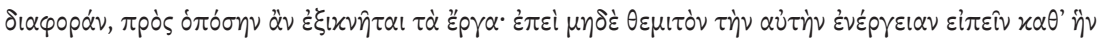

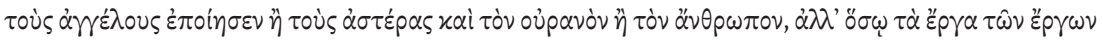

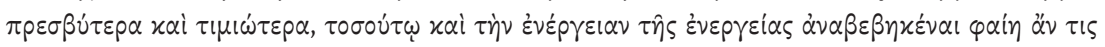

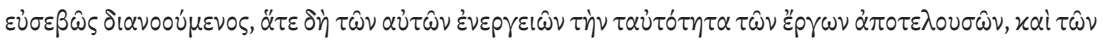

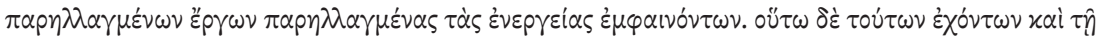

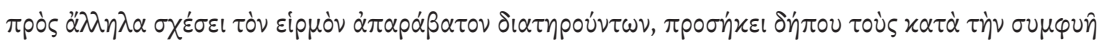

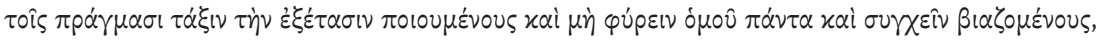

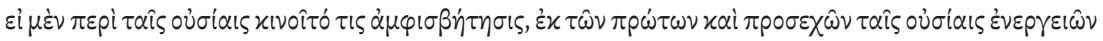

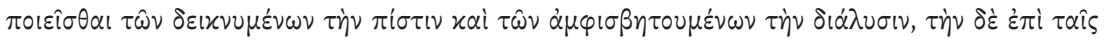

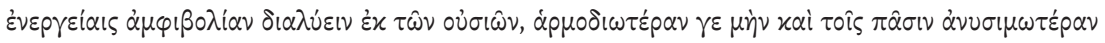

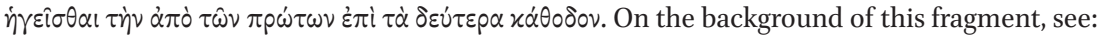
M. Barnes, “The Background and Use of Eunomius' Causal Language," In:Arianism after Arius. Essays on the Development of the Fourth Century Trinitarian Conflict, ed. M. Barnes, D. Williams, Edinburgh, 1993, pp. 220-222.

Gregorii Nysseni opera. Contra Eunomium Libri I et II, pars prior, p. 71.

3 Ibid., p. 78 . 
Thus, we do not apply the principle of 'more and the less' to substances. However, we do apply it to qualities (I.1.181-182 $)^{4}$.

Gregory here refers to the philosophical principle expressed in Aristotle's Categories (2b, 26-27, 3b 33ff) whereby a substance does not admit of degrees. Aristotle argues that with regard to primary substance (an individual), we cannot say that it relates to secondary substance (its species) in a greater or lesser degree than another primary substance, or that it is greater or lesser than itself at different points in time. Undoubtedly, Gregory of Nyssa was very familiar with Porphyry's Isagoge. ${ }^{5}$ In this work, Porphyry applies a similar principle to the thing as such. ${ }^{6}$ Additionally, we find this principle even more explicitly articulated in Porphyry's treatise On Aristotle's Categories, where it is explained using the example of human substance. Porphyry claims that, as an entity, a person (for example Socrates) cannot be more of a substance than himself or some other person. ${ }^{7}$ Gregory of Nyssa combines this principle with Aristotle's philosophical language, according to which individuals of a species participate in that species. ${ }^{8}$ He employs this in the interpretation of Porphyry, who asserts in the Isagoge that individuals participate in the species in the same way. ${ }^{9}$

Relying on the positions expressed in these sources, Gregory of Nyssa accuses Eunomius of being ignorant of the foundations of dialectics. This ignorance is what leads him to false premises in his theology. But Gregory also develops his own philosophy in connection with the principle of 'the more and the less,' which plays a comprehensive role in his theological system. ${ }^{10}$

4 Ibid., p. 80.

5 See D. Biriukov, "'Ascent of Nature from the Lower to the Perfect:' Synthesis of Biblical and Logical-Philosophical Descriptions of the Order of Natural Beings in the De opificio hominis 8 by Gregory of Nyssa," Scr, 11 (2015), pp. 208-215.

6 Porphyry, Isagoge 3 (Porphyrii isagoge et in Aristotelis categorias commentarium, ed. A.

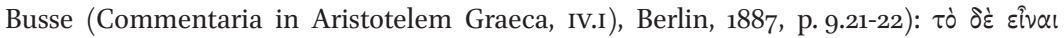

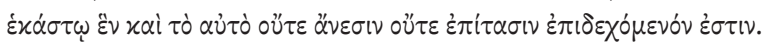

7 Idem, In Aristotelis categorias expositio (Porphyrii isagoge et in Aristotelis categorias commentarium, p. 97-7-22). In general regarding the contexts of the principle of 'the more and the less' and its interpretation in Porphyry's oeuvre see J. Barnes, "Commentary," in Porphyry, Introduction, trans. J. Barnes, Oxford, 2003, pp. 172-176.

8 Aristotle, Topica 121a10-15; 122b20-22.

9 Porphyry, Isagoge 10 (Porphyrii isagoge et in Aristotelis categorias commentarium, p. 17.3-8; 15, p. 21.14-17.

10 See Contra Eunomium I.1.270-277.13 (Gregorii Nysseni opera. Contra Eunomium Libri I et II, pars prior, pp. 105-107). Gregory demonstrates there how the principle of "the more or the less" can be applied to all domains of being. Gregory talks about the division of substances into classes. He distinguishes between intellectual and corporeal natures and divides the intellectual nature into created and uncreated ones. With regard to sensible nature, Gregory of Nyssa claims, the principle of "more or less" applies to qualities. 
In Against Eunomius 1.1.205, ${ }^{11}$ Gregory of Nyssa continues his examination of the passage from Eunomius. He arrives at the claim that "the activities accompanying each of the substances are lesser and greater" and investigates this paragraph in detail. In Against Eunomium I.1.317, he deals with the passage again. He quotes the words of Eunomius that angels, stars, and heaven are produced by different activities of God. However, instead of the original words that appear in Gregory's quotation of the Second Apology, where the principle of 'the more and the less' is applied to the activities (proceeding from the Father, the Son, and the Spirit) - ".... there is surely every necessity that the activities accompanying each of the substances are lesser and greater" ( $\alpha \dot{\alpha} \gamma \gamma \chi \eta$

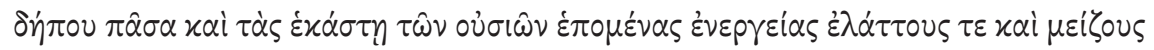

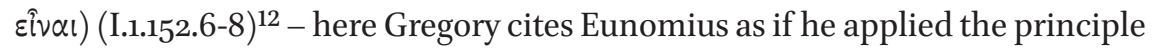
to substances: "necessity requires that the substances must be considered to be

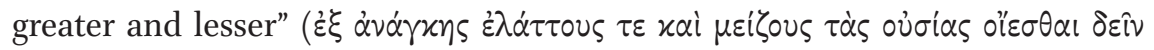
Eival) (I.1.317.2-3) ${ }^{13}$. Gregory also adduces Eunomius's words as if he applied the principle of "the more or the less" to substances in other parts of Against Eunomius as well, e.g. in I.1.282. ${ }^{14}$

I argue that there is no reason to doubt that Eunomius was referring to greater and lesser activities, not substances. The words of Eunomius's Second Apology, that "there is surely every necessity that the activities accompanying each of the substances are lesser and greater", which Gregory cites in the "main" extract from Eunomius at the beginning of Against Eunomius (I.1.152.6-8), express the principle proposed by Eunomius in his first Apology. ${ }^{15}$ This principle says that what we know a thing's nature from its activities. Thus, I conclude

Concerning the created intelligible nature (e.g. angels, and intellect as a part of human nature), Gregory notes that in this case we can apply the language of "more or less" not to a degree of qualities, but exclusively with respect to the a higher or a lower desire for the ultimate good, in connection to the disposition of will, and therefore with respect to a higher or lower participation in the Divine essence (here we can see a combination of Platonic discourse of participation with reference to 2 Pet. 1:4). However, concerning the uncreated intelligible nature, according to Gregory of Nyssa, the principle of "the more or the less" in participation cannot be applied. This is caused by the fact that the uncreated has the good by its nature and not by participation, as is the case with created substances. See D. Biriukov, “'Ascent of Nature from the Lower to the Perfect'," pp. 198-200.

11 Gregorii Nysseni opera. Contra Eunomium Libri I et II, pars prior, p. 86.

12 Ibid., p. 72.

13 Ibid., p. 121.

14 Ibid., p. 109.

15 Eunomius, Liber Apologeticus 20 (Eunomius, The Extant Works, text and translation by R. Vaggione, Oxford, 1987, pp. 58.7-9; 60.15-19). See R. Vaggione, Eunomius of Cyzicus and the Nicene Revolution, Oxford, 2000, pp. 130-132. 
these words are completely consistent with the teaching of Eunomius in general.

Concerning what is described by Gregory of Nyssa as Eunomius's teaching on greater and lesser substances, I argue that this doctrine does not really belong to Eunomius. This conclusion is based on the narrative structure of the reconstruction of the quotation from the Second Apology, what has been traced previously in this paper. An additional argument to back up my conclusion comes from the following observation.

Cyril of Alexandria testifies in his Thesaurus that Eunomius himself used the principle of 'the more and the less' in his philosophical polemics with the Nicenes. Based on the analysis of the Thesaurus, we can conclude that Eunomius, like his opponent, denied that it was eligible to apply the principle of 'the more and the less' to substance. Eunomius claimed that the Father and the Son cannot be of the same nature, because with respect to the nature (i.e. their common, generic nature) there is no way to be more or less. However, owing to what the Son says about the Father, that "the Father is greater than I" (John 14:28), Eunomius concludes that the only way to explain this statement form the Gospel is to admit that the Son and the Father have different natures._ 1617

16 See: "Those who received the same nature and who are of the same nature ( $\dot{\phi} \mu \circ \varphi \hat{\eta})$ have neither something more with regard to the nature nor less. For neither is a man more of a man than another with regard to the nature, nor a horse is more of a horse than others. Therefore, if the Son says that the Father is greater than I, and we know that a consubstantial would not be greater than another consubstantial with respect to the logos of the substance, consequently the Son is not consubstantial with the Father" (Cyril of Alexandria, Thesaurus 11: PG 75, col. 140B-C). Cf. Eunomius, The Extant Works, p. 183; Vaggione, Eunomius of Cyzicus, p. 164.

17 Basil of Caesarea also by implication testifies, with respect to my argument, that the teaching of Eunomius does not include the application of the principle of 'the more and the less' to substance. While refuting the positions from the first Apology, Basil, in his Against Eunomius (PG 29b, col. 565-566), commenting on Eunomius's understanding of John 14:28 ("the Father is greater than I") says that, according to Eunomius, the effect is always ontologically lesser than its cause. Thus, the substance of the Son, according to Eunomius, is not the same as the substance of the Father. Basil writes: "Generally speaking, a substance is not said to be greater or lesser than a substance, even according to your wisdom" (1.25, PG 29b, col. 568; Basile de Césarée, Contre Eunome, suivi de Eunome, Apologie, T. 1, introd., trad. et notes de B. Sesboüé, avec la collab. pour le texte et l'introd. critiques de G.M. de Durand et L. Doutreleau, Paris, 1982 (sc 299), p. 262; St. Basil of Caesarea, Against Eunomius, trans. by M. DelCogliano and A. Radde-Gallwitz (The Fathers of the

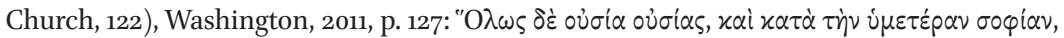

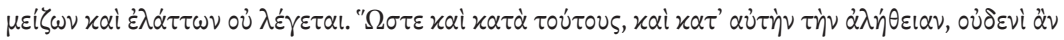


To my knowledge, no study thus far has pointed out this disparity between the words of Eunomius cited in Against Eunomius 1.1.151-154 and the way Gregory represents Eunomius' position, interpreting it further and citing him later in the course of the treatise. Moreover, some scholars misleadingly represent Eunomius's position based solely on the words of Gregory of Nyssa that Eunomius applied the principle of 'the more and the less' to substance. ${ }^{18}$

To sum up I make two conclusions:

Firstly, Gregory of Nyssa at the outset of his Against Eunomius cites Eunomius, where the latter speaks particularly about "greater and lesser" activities. However, discussing this quotation later in the treatise, Gregory of Nyssa misinterprets the words of Eunomius. He reads Eunomius as if he applied the principle of 'the more and the less' not to activities but to substances. ${ }^{19}$ As I have demonstrated in this essay, such interpretation cannot be proved on the basis of what Eunomius actually wrote. At the same time, Gregory of Nyssa built an important part of his philosophical polemic on this false interpreta-

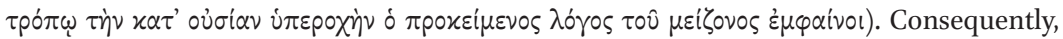
I conclude that according to Basil, Eunomius did not apply the principle of 'the more and the less' to the category of substance.

18 See D. Balás, METOY $I A$ OEOY: Man's participation in God's perfections according to St. Gregory of Nyssa, Rome, 1966, pp. 57, 125, 130; L. Turcescu, Gregory of Nyssa and the Concept of Divine Persons, Oxford University Press, 2005, p. 29. In both studies the authors argue that Eunomius applies the principle of 'the more and the less' to substance, i.e. to the substances of the Father and the Son.

There is another instance of how misleadingly Gregory of Nyssa can cite other people's work. As David Balás has shown, Gregory, in commenting upon Basil's Against Eunomium 2.4 in his own work against Eunomius, emphasizes the Platonic understanding of human nature as a generic substance common to all human beings and existing in each individual, as opposed to Basil's emphasis on the understanding of a single nature of human beings in terms of a common substrate; see PG 29b. cols. 577c-58ob; Basile de Césarée, Contre Eunome, suivi de Eunome, Apologie, T. 2, ed. B. Sesboüé, G.M. de Durand, L. Doutreleau (sc, 305), Paris, 1983, p. 20.11-12. When Gregory cites Basil's passage under discussion

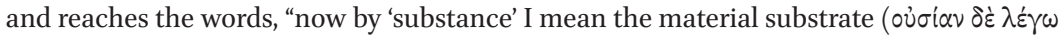

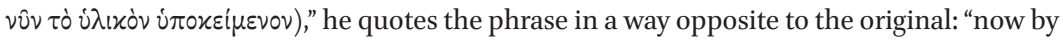

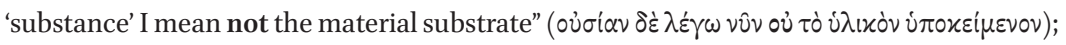
Gregorius Nyssenus, Contra Eunomium III.5.22.7-8 (Gregorii Nysseni opera. Contra Eunomium Libri I et II, pars altera, ed. W. Jaeger, Leiden, 1960, p. 168). Balás pays particular attention to this fact, assuming that Gregory corrected the passage because it did fit in with his own views and with the needs of his polemic against Eunomius. See D. Balás, "The Unity of Human Nature in Basil's and Gregory of Nyssa's Polemics against Eunomius," Studia Patristica 14.5 (1976), pp. 278-279. 
tion of Eunomius. Within the framework of this polemic he developed his own philosophical system founded on the principle of 'the more and the less'.

Secondly, the two opponents (Gregory of Nyssa and Eunomius) used the same Aristotelian position, which prohibits the application of the principle of 'the more and the less' to the category of substance. This position was used by the two polemists in order to argue against each other. 